\title{
Response of Broilers to Practical Diets with Different Metabolizable Energy and Balanced Protein Concentrations
}

\section{author(s)}

Aftab U

Sadiq Poultry (Pvt) Ltd. Rawalpindi, Pakistan

\section{Mail Address}

Usama Aftab

E-mail: usamaaftab@yahoo.com

\section{Keywords}

Balanced protein, broilers, metabolizable energy.

\section{ABSTRACT}

Experiment was conducted to study the effect of Metabolizable Energy (ME) and Balanced Protein (BP) on the performance of 1- to 35day-old male and female Hubbard x Hubbard broilers. Set in a factorial arrangement, dietary treatments involved 3 levels of ME (2650, 2750, or $2850 \mathrm{kcal}$ per kg diet) and 4 levels of Balanced Protein (expressed as 8.4, 9.0, 9.6, or $10.2 \mathrm{~g}$ Standardized lleal Digestible lysine per kg). Each diet was fed to 5 replicate pens of 17 chicks. Dietary ME and BP did not interact for any of the parameters studied ( $p>0.05)$. The main effect of ME was significant $(p<0.05)$ for feed intake, body weight, and feed conversion ratio at all ages. Highest ME $(2850 \mathrm{kcal})$ resulted in 35 day feed intake and feed conversion ratio that was significantly $(p<0.05)$ low compared with those fed on lower levels of ME; while 35 day body weight was significantly $(p<0.05)$ high at $2850 \mathrm{kcal}$ compared with 2650 kcal ME. Feed intake and body weight improved linearly $(p<0.05)$ with increasing BP from 8.4 to $10.2 \mathrm{~g}$ per $\mathrm{kg}$, while the BP did not have any effect on feed conversion ratio. Dietary combinations of ME and BP to optimize body weight and feed conversion ratio are suggested on weekly basis.

\section{INTRODUCTION}

Broilers have a remarkable capacity to achieve certain weight gain according to age by modifying voluntary feed intake when offered an array of dietary energy contents (ME; NRC 1994; Leeson et al., 1996). In this context, the decision regarding 'optimum' dietary level of ME seems merely a function of the price of energy sources and the premium achieved for improved Feed Conversion Ratio (FCR).

The requirements of broilers for various amino acids during different growout phases have been extensively studied. In general, two methodologies have been used to study the responses to individual amino acids: graded supplementation (Mack et al., 1999; Baker et al., 2002; Aftab et al., 2007) and diet dilution (Gous \& Morris 1985). The common aspect between these two techniques is that, except for the amino acid under investigation, amino acids are supplied in large excess. In commercial feed formulation, the luxury of oversupplying amino acids is not justified. For instance, a typical broiler diet formulated with crystalline methionine, lysine, and threonine with no minimum Crude Protein (CP) often contains a balance, suggesting that the four or five most 'critical amino acids' are equally limiting. In current study, the response of amino acids in terms of Balanced Protein (BP) was evaluated with an idea that it conforms more closely to the commercial dietary conditions where large excess of essential and nonessential amino acids is avoided. 


\section{MATERIALS AND METHODS}

\section{General}

A total of 2000 male and female day-old chicks (Hubbard $x$ Hubbard) were obtained from a commercial hatchery. After provided free access to drinking water for four hours, chicks were individually weighed and distributed into three weight categories. Out of the intermediate-weight category, discarding the lower and higher weight groups, a total of 1020 chicks were randomly distributed to 60 floor pens $(17$ chicks per pen), maintaining similar cumulative body weight and range among all pens. Rice husks were used as litter (2-inche depth). Each pen was equipped with a bell drinker and a tube feeder. Feed and water were supplied ad libitum, and 24 hours of light was provided throughout the experimental period. All birds were submitted to a vaccination program (New Castle Disease, Infectious Bronchitis, Infectious Bursal Disease, and Hydropericardium Syndrome) scheduled according to the local practice.

\section{Diets and experimental design}

Experimental diets were least-cost formulated using current ingredient prices (November 2008). Each feed ingredient was individually mixed in a batch mixer (2 tons) in order to ensure constant quality of the ingredients across experimental diets. Two basal diets were formulated to contain BP levels of 8.4 (low) or 10.2 (high) Standardized lleal Digestible (SID) lysine and $2650 \mathrm{kcal}$ ME per kg. All other EAA (essential amino acids) were set to meet or exceed the Ideal Ratios relative to lysine (Baker \& Han 1994). Higher ME levels (2750 and $2850 \mathrm{kcal}$ ) were achieved by a two-step replacement of half or all wheat bran by sunflower oil (on weight basis), resulting in six diets (Table 1). Within each ME level, intermediate levels of BP (9.0 and 9.6 g) were prepared by blending 8.4 and $10.2 \mathrm{~g} \mathrm{BP}$ diets

\begin{tabular}{|c|c|c|c|c|c|c|}
\hline \multirow{2}{*}{$\begin{array}{l}\text { AMEn, kcal }{ }^{1} \\
\text { BP, g per } \text { kg }^{2}\end{array}$} & \multicolumn{2}{|c|}{ - 2650} & \multicolumn{2}{|c|}{ - 2750} & \multicolumn{2}{|c|}{ 2850 } \\
\hline & 8.4 & 10.2 & 8.4 & 10.2 & 8.4 & 10.2 \\
\hline \multicolumn{7}{|l|}{ Ingredients } \\
\hline Corn & 51.9 & 43.0 & 51.9 & 43.0 & 51.9 & 43.0 \\
\hline Rice polishing & 12.0 & 12.0 & 12.0 & 12.0 & 12.0 & 12.0 \\
\hline Wheat bran & 2.6 & 2.6 & 1.3 & 1.3 & - & - \\
\hline Soybean meal, $45 \%$ CP & 8.0 & 14.0 & 8.0 & 14.0 & 8.0 & 14.0 \\
\hline Canola meal, 38\% CP & 8.0 & 12.0 & 8.0 & 12.0 & 8.0 & 12.0 \\
\hline Sunflower meal, $30 \%$ CP & 13.4 & 11.1 & 13.4 & 11.1 & 13.4 & 11.1 \\
\hline Sunflower oil & - & 1.35 & 1.30 & 2.65 & 2.60 & 3.95 \\
\hline Limestone & 0.6 & 0.6 & 0.6 & 0.6 & 0.6 & 0.6 \\
\hline Bone meal & 2.5 & 2.3 & 2.5 & 2.3 & 2.5 & 2.3 \\
\hline Salt & 0.4 & 0.4 & 0.4 & 0.4 & 0.4 & 0.4 \\
\hline I-lysine HCL & 0.227 & 0.233 & 0.227 & 0.233 & 0.227 & 0.233 \\
\hline dl-methionine & 0.038 & 0.110 & 0.038 & 0.110 & 0.038 & 0.110 \\
\hline I-threonine & - & 0.017 & - & 0.017 & - & 0.017 \\
\hline Vit/min premix $^{3}$ & 0.3 & 0.3 & 0.3 & 0.3 & 0.3 & 0.3 \\
\hline Phytase premix ${ }^{4}$ & 0.1 & 0.1 & 0.1 & 0.1 & 0.1 & 0.1 \\
\hline Total & 100.1 & 100.1 & 100.1 & 100.1 & 100.1 & 100.1 \\
\hline \multicolumn{7}{|l|}{ Calculated analysis } \\
\hline AMEn, kcal per kg & 2650 & 2650 & 2750 & 2750 & 2850 & 2850 \\
\hline Crude Protein, g per kg & 178 & 206 & 178 & 206 & 178 & 206 \\
\hline SID lysine, g per kg & 8.4 & 10.2 & 8.4 & 10.2 & 8.4 & 10.2 \\
\hline SID M+C/lysine & 76 & 76 & 76 & 76 & 76 & 76 \\
\hline SID threonine/lysine & 67 & 67 & 67 & 67 & 67 & 67 \\
\hline SID isoleucine/lysine & 73 & 71 & 73 & 71 & 73 & 71 \\
\hline SID valine/lysine & 89 & 85 & 89 & 85 & 89 & 85 \\
\hline SID tryptophan/lysine & 19 & 20 & 19 & 20 & 19 & 20 \\
\hline SID arginine/lysine & 125 & 122 & 125 & 122 & 125 & 122 \\
\hline Calcium, g per kg & 8.0 & 8.0 & 8.0 & 8.0 & 8.0 & 8.0 \\
\hline Av. Phosphorus, g per kg & 4.0 & 4.0 & 4.0 & 4.0 & 4.0 & 4.0 \\
\hline Sodium, $\mathrm{g}$ per $\mathrm{kg}$ & 2.2 & 2.2 & 2.2 & 2.2 & 2.2 & 2.2 \\
\hline
\end{tabular}

1 - Difference in ME was achieved essentially by proportionate replacement of wheat bran with sunflower oil keeping all other ingredients unchanged. 2 - Balanced Protein expressed as Standardized lleal Digestible lysine, where all other essential amino acids were set to meet or exceed the Ideal Ratios (Baker and Han, 1994). Within each ME, intermediate levels of BP $(9.0$ and $9.6 \mathrm{~g})$ were prepared, respectively by blending 8.4 and $10.2 \mathrm{~g} \mathrm{BP}$ diets in 67:33 and 33:67 (W/W) proportions. 3 = Provided per kg of diet: vitamin A, 8000 IU; cholecalciferol, 2000 ICU; vitamin E, 30 mg; menadione, 2 mg; riboflavin, $5.5 \mathrm{mg}$; pantothenic acid, $13 \mathrm{mg}$; niacin, $36 \mathrm{mg}$; choline, $500 \mathrm{mg}$; vitamin B12, $0.02 \mathrm{mg}$; folic acid, $0.5 \mathrm{mg}$; thiamin, 1 mg; pyridoxine, 2.2 mg; biotin, 0.05 mg; ethoxiquin, 125 mg; Mn, 65 mg; Fe, 55 mg; Cu, 6 mg; Zn; 55 mg. 4 - Phyzyme XP TPT (Danisco Animal Nutrition, UK) to furnish 500 FTU per $\mathrm{kg}$ of finished feed. 
in 67:33 and 33:67 (WN) proportions, respectively. Each diet was fed as coarse mash to 5 replicate pens of 17 chicks from 1 to 35 days posthatch. Feed intake (FI) and Body weight (BW) were recorded weekly on pen basis, and the data was used to calculate FCR (feed conversion ratio). Mortality was recorded on daily basis, and dead weight recorded to correct FCR. The obtained live performance parameters were analyzed by the General Linear Model procedures, using MINITAB release 11.12. Means were compared using Tukey's test.

\section{RESULTS AND DISCUSSION}

Dietary ME and BP interaction had no effect on any of the parameters studied ( $p>0.05$ ). Main effect of $M E$ was significant $(p<0.05)$ for $\mathrm{Fl}, \mathrm{BW}$, and FCR at all ages. High ME $(2850 \mathrm{kcal})$ resulted in significantly lower 35-day $\mathrm{Fl}$ and FCR $(p<0.05)$ as compared with low ME level, while 35-day BW was significantly $(p<0.05)$ higher when 2850 kcal was fed as compared with 2650 kcal ME. Fl linearly responded to $\mathrm{BP}$ increase, where the total difference between BP extremes was about 3\% in this phase. BW linearly improved up to the highest level of BP and this effect was consistent across all ages, although the magnitude of effect seemed to decrease with age (Table 3). No effect of BP was apparent on FCR (Table 4). Mortality was lower than $2.6 \%$ in all treatments, and no appreciable treatment effect was observed (data not presented).

\begin{tabular}{|c|c|c|c|c|c|c|}
\hline $\mathrm{ME}, \mathrm{kcal} / \mathrm{kg}$ & $B P, g / k g$ & $7 d$ & $14 d$ & 21d & $28 d$ & $35 d$ \\
\hline 2650 & - & $157 b$ & $572 b$ & $1237 b$ & $2329 b$ & $3602 b$ \\
\hline 2750 & - & $155 b$ & $572 b$ & $1231 b$ & $2332 b$ & $3605 b$ \\
\hline 2850 & - & $149 a$ & $558 a$ & 1199a & $2267 a$ & $3472 a$ \\
\hline SEM & & 0.34 & 0.56 & 0.79 & 1.17 & 1.53 \\
\hline- & 8.4 & $150 x$ & $559 x$ & $1202 x$ & 2264 & 3507 \\
\hline- & 9.0 & $152 x$ & $559 x$ & $1215 x y$ & 2318 & 3554 \\
\hline- & 9.6 & $154 x y$ & $574 y$ & $1237 y$ & 2316 & 3564 \\
\hline- & 10.2 & $158 y$ & $577 y$ & $1235 y$ & 2341 & 3612 \\
\hline SEM & & 0.35 & $\begin{array}{c}0.55 \\
\text { Probab }\end{array}$ & 0.80 & 1.18 & 1.58 \\
\hline \multicolumn{7}{|l|}{ ANOVA } \\
\hline$M E$ & & 0.001 & 0.020 & 0.003 & 0.016 & 0.006 \\
\hline BP & & 0.006 & 0.004 & 0.022 & 0.061 & 0.267 \\
\hline $\begin{array}{l}\text { ME } \times \text { BP } \\
\text { Linear }\end{array}$ & & 0.281 & 0.284 & 0.330 & 0.200 & 0.790 \\
\hline$M E$ & & 0.179 & 0.333 & 0.240 & 0.359 & 0.346 \\
\hline $\begin{array}{c}\text { BP } \\
\text { Quadratic }\end{array}$ & & 0.017 & 0.073 & 0.068 & 0.092 & 0.026 \\
\hline $\mathrm{ME}$ & & - & - & - & - & - \\
\hline BP & & 0.076 & 0.363 & 0.254 & 0.329 & 0.225 \\
\hline
\end{tabular}

$a-z$ - Means within row for ME and BP with no common superscript differ significantly $(p<0.05)$.

\begin{tabular}{|c|c|c|c|c|c|c|}
\hline $\mathrm{ME}$, kcal/kg & BP, $\mathrm{g} / \mathrm{kg}$ & $7 d$ & $14 d$ & 21d & $28 d$ & $35 d$ \\
\hline 2650 & - & $159 b$ & 379 & $699 a$ & $1154 a$ & $1612 a$ \\
\hline 2750 & - & $159 b$ & 384 & $710 a b$ & $1182 b$ & $1665 a b$ \\
\hline 2850 & - & $155 a$ & 382 & $724 b$ & $1205 b$ & $1694 b$ \\
\hline SEM & & 0.33 & 0.52 & 0.72 & 0.81 & 1.08 \\
\hline- & 8.4 & $152 x$ & $364 x$ & $687 x$ & $1149 x$ & 1633 \\
\hline - & 9.0 & $156 x y$ & $380 y$ & $708 x y$ & $1178 x y$ & 1652 \\
\hline- & 9.6 & $158 y$ & $386 y z$ & $725 y$ & $1185 y$ & 1664 \\
\hline- & 10.2 & $164 z$ & $396 z$ & $725 y$ & $1208 y$ & 1678 \\
\hline SEM & & 0.30 & $\begin{array}{c}0.43 \\
\text { Probab }\end{array}$ & 0.69 & 0.81 & 1.13 \\
\hline \multicolumn{7}{|l|}{ ANOVA } \\
\hline$M E$ & & 0.015 & 0.379 & 0.014 & 0.001 & 0.002 \\
\hline$B P$ & & 0.001 & 0.001 & 0.001 & 0.001 & 0.362 \\
\hline \multicolumn{6}{|l|}{ Linear } & 0.512 \\
\hline $\mathrm{ME}$ & & 0.333 & 0.593 & 0.044 & 0.036 & 0.107 \\
\hline \multicolumn{7}{|l|}{ Quadratic } \\
\hline$M E$ & & - & - & - & - & - \\
\hline BP & & 0.155 & 0.135 & 0.093 & 0.202 & 0.061 \\
\hline
\end{tabular}

a-z Means within row for ME and BP with no common superscript differ significantly $(p<0.05)$. 


\begin{tabular}{|c|c|c|c|c|c|c|}
\hline $\mathrm{ME}, \mathrm{kcal} / \mathrm{kg}$ & $B P, g / k g$ & $7 d$ & $14 d$ & 21d & $28 d$ & $35 d$ \\
\hline 2650 & - & 0.986 & $1.511 \mathrm{~b}$ & $1.770 b$ & $2.019 b$ & $2.237 b$ \\
\hline 2750 & - & 0.976 & 1.492ab & $1.737 b$ & $1.975 b$ & $2.169 b$ \\
\hline 2850 & - & 0.964 & $1.464 a$ & $1.658 a$ & $1.883 a$ & $2.051 a$ \\
\hline SEM & & 0.028 & 0.031 & 0.034 & 0.034 & 0.041 \\
\hline- & 8.4 & 0.991 & $1.535 y$ & 1.752 & 1.974 & 2.151 \\
\hline - & 9.0 & 0.972 & $1.473 x$ & 1.718 & 1.969 & 2.157 \\
\hline - & 9.6 & 0.969 & $1.489 x$ & 1.711 & 1.954 & 2.144 \\
\hline - & 10.2 & 0.969 & $1.461 x$ & 1.705 & 1.939 & 2.157 \\
\hline SEM & & 0.028 & 0.030 & 0.037 & 0.039 & 0.046 \\
\hline & & 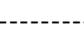 & Probabi &.--- & & \\
\hline \multicolumn{7}{|l|}{ ANOVA } \\
\hline $\mathrm{ME}$ & & 0.307 & 0.019 & 0.001 & 0.001 & 0.001 \\
\hline $\mathrm{BP}$ & & 0.503 & 0.001 & 0.242 & 0.505 & 0.985 \\
\hline $\begin{array}{l}\text { ME } \times \text { BP } \\
\text { Linear }\end{array}$ & & 0.144 & 0.287 & 0.395 & 0.099 & 0.507 \\
\hline $\mathrm{ME}$ & & 0.033 & 0.070 & 0.148 & 0.128 & 0.098 \\
\hline $\begin{array}{c}\text { BP } \\
\text { Quadratic }\end{array}$ & & 0.159 & 0.180 & 0.091 & 0.020 & 0.896 \\
\hline $\mathrm{ME}$ & & - & - & - & - & - \\
\hline BP & & 0.158 & 0.486 & 0.160 & 0.082 & 0.939 \\
\hline
\end{tabular}

a-z Means within row for ME and BP with no common superscript differ significantly $(p<0.05)$.

In general, the data presented herein suggest that the effect of ME and BP on BW was age dependent, as the requirement of $\mathrm{ME}$ tended to increase and that of BP to decrease with age. High ME (2850 kcal per $\mathrm{kg}$ ) resulted in the lowest BW at 7 days posthatch, followed by no effect of ME on BW at 14 days posthatch, and a reverse situation at 35 days of age, when $2850 \mathrm{kcal}$ EM resulted in approximately 5\% higher BW as compared with that promoted by 2650 $\mathrm{kcal}(p<0.01)$. In contrast, the effect of BP on BW was very pronounced during the first two weeks of age (e.g. about $8.4 \%$ difference between 10.2 vs. $8.4 \mathrm{~g}$ $\mathrm{BP})$. This effect, however, tended to decrease at 21 and 28 days posthatch (about $5.2 \%$ ) and was further reduced to $2.8 \%$ at 35 days posthatch. Increasing BP caused a significant linear increase in $\mathrm{Fl}$, an observation that contrasts with the reports demonstrating a slight depression in $\mathrm{Fl}$, and hence an improved $F C R$, in response to increased levels of dietary BP and/or amino acids (Mack et al., 1999; Baker et al., 2002; Wijtten et al., 2004; Lemme et al., 2006). Differences in the inclusion of dietary ingredients between diets containing different BP concentrations in our study may partly explain this apparent anomaly.

The results of present study demonstrated that the impact of BP on BW was strictly linear, and no apparent plateau was reached up to the highest BP level, suggesting that the 'requirement' of broilers for BP could have been even higher than those observed in the current study. Conversely, our previous experiments using similarly low ME basal diets, but making use of the conventional graded-supplementation approach, suggested that digestible lysine requirement for BW was 0.85 and $0.75 \%$ of diet, respectively during the starter and grower/finisher phase (Aftab et al., 2007). In this respect, findings of the current study seems to agree with those reported by Wijtten et al. (2004), who demonstrated that broiler weight gain broilers responded to higher dietary Ideal Protein (or BP) levels than would be expected from single lysine requirement studies in literature. In contrast, when comparing graded-supplementation (only the concentration of amino acid in question is changed) vs. diet-dilution techniques (complete range of essential and nonessential amino acids is changed), D'Mello (1982) concluded that amino acid requirements were independent of the methodology used. It is, however, worthy noting that the diet-dilution technique makes use of large excesses of amino acids (other than one under study), and thus do not supply BP.

The comparison of the response to the $8.4 \mathrm{~g}$ digestible lysine treatment in our study with that of $8.5 \mathrm{~g}$ digestible lysine in the study of Plumstead et al. (2007) suggests that the efficiency of lysine utilization for weight gain was markedly high when offered as a fairly balanced protein (17.8\% CP in our study) vs. when the same dietary concentration of lysine was fed in the presence of 'excessive/imbalanced' protein (22\% CP in Plumstead et al., 2007). This finding seems to be consistent with earlier reports suggesting that the efficiency of utilization of first limiting amino acid was depressed in the presence of surplus CP (Morris et al., 
1999). In view of the arguments presented above, as well as for the purpose of practical applications, it seems more defendable to study the amino acid responses in terms of BP rather than using a graded-supplementation or diet dilution techniques.

\section{CONCLUSION}

Dietary ME and BP interaction did not influence any of the studied parameters, and the main effect of $\mathrm{ME}$ and BP on BW and FCR was age dependent. Optimum dietary combinations of $\mathrm{ME}$ and $\mathrm{BP}$ for $\mathrm{BW}$ seems to be 2650/10.2, 2650/9.6, 2750/9.0, and 2750/8.4, respectively, for the periods of $1-7,8-14,15-21$, and 22-35 days of age, whereas for FCR, these combinations are, 2650/8.4, 2750/9.0, and 2850/8.4, respectively, for the periods of $1-7,8-14$, and $15-35$ days of age.

\section{REFERENCES}

Aftab U, Ashraf M, Mumtaz AS, Jiang Z. Lysine requirement of broiler chickens fed low-density diets under tropical conditions. Asian-Australasian Journal of Animal Science 2007; 20:939-943.

Baker DH, Batal AB, Parr TM, Augspurger NR, Parsons CM. Ideal ratio (relative to lysine) of tryptophan, threonine, isoleucine, and valine for chicks during the second and third weeks posthatch. Poultry Science 2002; 81:485-494.

Baker DH, Han Y. Ideal amino acid profile for chicks during the first three weeks posthatching. Poultry Science 1999; 73:1441-1447.

D'Mello JPF. A comparison of two empirical methods of determining amino acid requirements. World's Poultry Science Journal 1982; 38:114-119.

Gous MR, Morris TR. Evaluation of a diet dilution technique for measuring the response of broiler chickens to increasing concentration of lysine. British Poultry Science 1985; 26:147-161.

Lemme A, Wijtten PJA, van Wichen, Petri A, Langhout DJ. Responses of male growing broilers to increasing levels of balanced protein offered as coarse mash or pellets of varying quality. Poultry Science 2006; 85:721-730.

Lesson S, Caston L, Summers JD. Broiler response to energy or protein dilution in finisher diet. Poultry Science 1996; 75:522-528.

Mack S, Bercovici D, De Groote G, Leclercq B, Lippens M, Pack M, Schutte JB, van Cauwenberghe. Ideal amino acid profile and dietary lysine specification for broiler chickens of 20 to 40 days of age. British Poultry Science 1999; 40:257-265.

Morris TR, Gous RM, Fisher C. An analysis of the hypothesis that amino acid requirements for chicks should be stated as proportion of dietary protein. World's Poultry Science Journal 1999; 55:7-22.
National Research Council. Nutrient requirements of poultry. 9th ed. Washington DC; 1994.

Plumstead PW, Romero-Sanchez H, Paton ND, Spears JW, Brake J. Effects of dietary metabolizable energy and protein on early growth responses of broilers to dietary lysine. Poultry Science 2007; 86: 2639-2648.

Wijtten PJA, Prak R, Lemme A, Langhout DJ. Effect of different dietary ideal protein concentrations on broiler performance. British Poultry Science 2004; 45:504-511. 


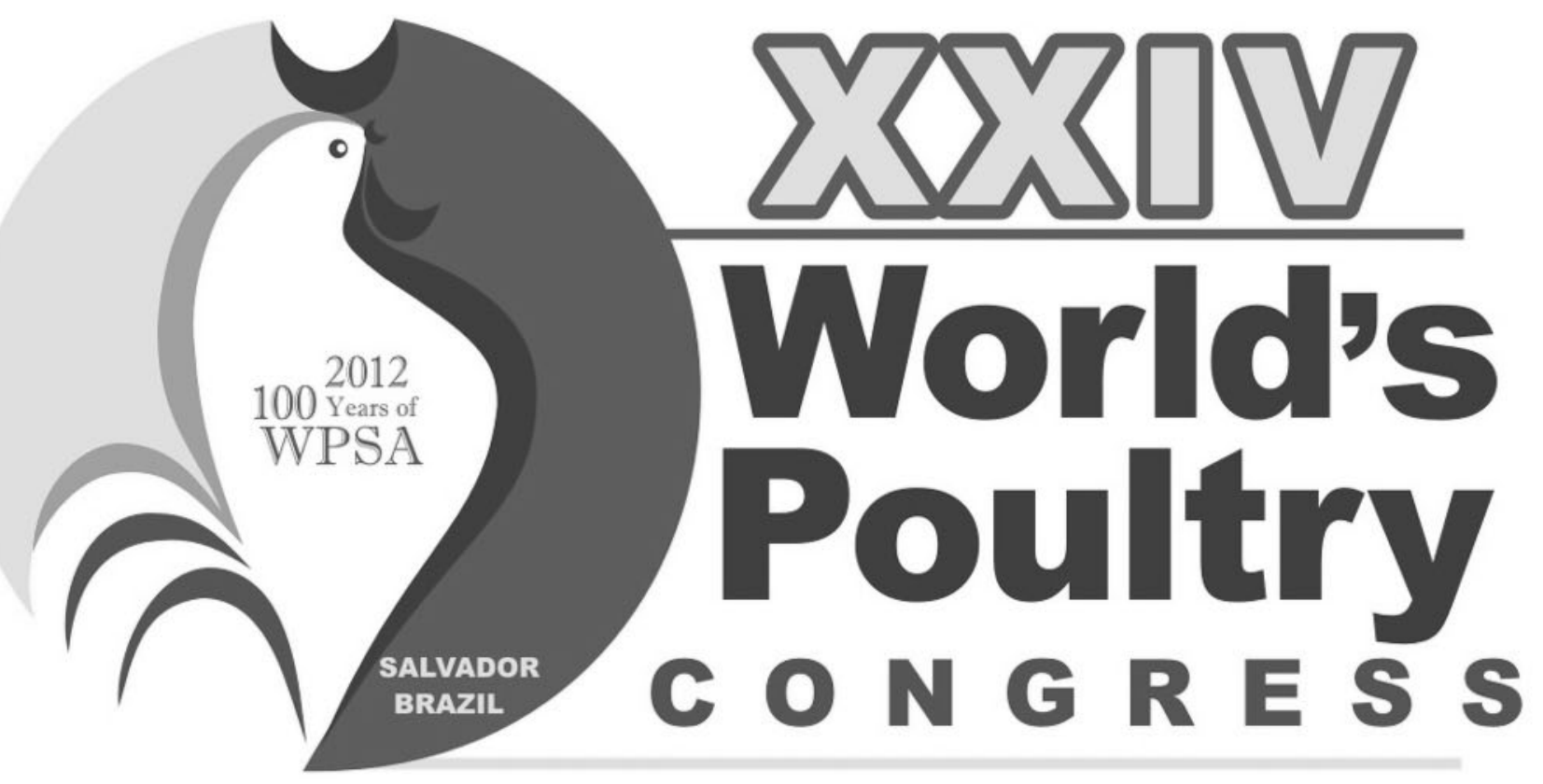

\section{5 - 08 August 2012 Salvador - Bahia - Brazil}

\section{wWw.wpc2012.com}

Organization and Promotion
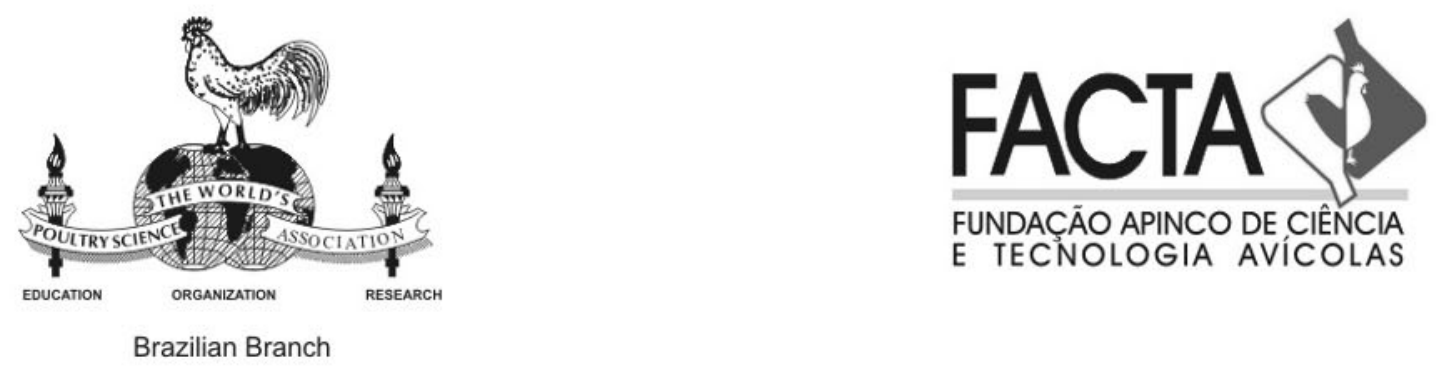